\title{
Doğaya Saygı İle Çevrecilik Değerlerinin Tüketicilerin Marka Deneyimine Etkisi Üzerine Bir Araştırma (A Research on the Effect of Respect for Nature and Environmentalist Values on the Brand Experience of Consumers)
}

\section{Tuğba UZUNKAYA iD a}

${ }^{a}$ Kocaeli Üniversitesi, Gazanfer Bilge Meslek Yüksek Okulu, Kocaeli, Türkiye. tugba.uzunkaya@kocaeli.edu.tr

\begin{tabular}{ll}
\hline MAKALE BILGİSI & ÖZET \\
\hline Anahtar Kelimeler: & Amaç - Çevrecilik değerleri, doğaya saygı ve bireyin sahip olduğu çevresel öz varlıkları içermektedir. \\
Doğaya Saygı & $\begin{array}{l}\text { Çalı̧mada, doğaya saygı ve bireyin sahip olduğu öz varlıkların, çevre dostu marka deneyimini; çevre } \\
\text { dostu marka deneyiminin de genel marka deneyimini, olumlu yönde etkileyip etkilemediğini analiz } \\
\text { Çevresel Öz Varlıklar }\end{array}$ \\
Marka Deneyimi & etmek amaçlanmıştır.
\end{tabular}

Marka Deneyimi

Yöntem - Çalışmada, sürdürülebilirlik konusunda çevre dostu teknolojiye önem veren, Apple ve Samsung markaları baz alınmıştır. Veriler, akıllı cihaz kullanan tüketicilerden, online anket yöntemiyle toplanmıştır ve ilişkileri test etmek için Yapısal Eşitlik Modellemesi kullanılmıştır. Araştırmanın evreni,

Gönderilme Tarihi 10 Kasım 2020

Revizyon Tarihi 15 Mart

2021

Kabul Tarihi 27 Mart 2021

Makale Kategorisi:

Araştırma Makalesi
18 yaş ve üzeri akıllı cihaz kullanan tüketicilerden oluşmaktadır. Evrene ulaşılmasının pratikte mümkün olmadığı dikkate alınarak örnekleme yapılmıştır. Evren ile ilgili bir genelleme yapma hedefi öngörülmediğinden tesadüfi olmayan örnekleme yöntemlerinde kolayda örnekleme yöntemi kullanılmıştır. Buna göre, araştırmanın katılımcıları, 18 yaş üstü, söz konusu iki marka akıllı cihazdan birini kullanan, 302 kişiden oluşmaktadır

Bulgular - Analiz sonucunda, doğaya saygının, çevre dostu marka deneyimine etkisi istatistiksel olarak anlamlı çımazken, bireyin sahip olduğu öz varlıkların çevre dostu marka deneyimine etkisi anlamlı bulunmuştur. Çevre dostu marka deneyiminin ise, genel marka deneyimini olumlu yönde etkilediği sonucuna ulaşılmıştır.

Tartışma - Doğaya saygı ve bireyin çevreye ilişkin sahip olduğu öz varlıklar, kişisel çevre dostu davranışsal niyetleri açılayan önemli öncüller olarak düşünülebilir. Markaların, müşterileriyle olan iletişimlerinde, çevreci marka deneyimi yaşamalarını sağlamaları, tüketicilerin genel marka deneyimlerini olumlu yönde şekillendirmektedir. Dolayısıyla markaların, çevreci politikalarını ön plana çıkararak, bu konuda müşterilerine daha fazla bilgi sunmaları ve farkındalığı artırmaları, çalışmada ele alınan, çevreci yaklaşımın önemini vurgular niteliktedir.

\section{ARTICLE INFO}

ABSTRACT

\section{Keywords:}

Respect for Nature Environmental Self-Assets Brand Experience

Received 10 November 2020 Revised 15 March 2021

Accepted 27 March 2021

Article Classification: Research Article
Purpose - Environmentalist values refer to respect for nature and environmental self-assets. In this study, it is aimed to analyze whether respect for nature and the environmental self-assets positively affect the environmentally-friendly brand experience, and whether the environmentally-friendly brand experience also affects the overall brand experience in a positive way.

Design/methodology/approach - The study was based on the Apple and Samsung brands, which attach importance to environmentally-friendly technology for sustainability. Data was collected from consumers using smart devices by online survey method and Structural Equation Model was used to test the relationships. The research population consists of consumers aged 18 and over who use smart devices. Sampling was performed considering that it is practically impossible to reach the population. Since the goal of generalizing about the population was not envisaged, the convenience sampling method was used in non-random sampling methods. Accordingly, the participants of the study consisted of 302 people over the age of 18 , using one of the two brands of smart devices mentioned.

Findings - As a result of the analysis, it was determined that the effect of respect for nature on the environmentally-friendly brand experience was not statistically significant, while the effect of the environmental self-assets on the environmentally friendly brand experience was found to be significant. It was concluded that the environmentally-friendly brand experience positively affected the overall brand experience.

Discussion - Consumers' environmental self-assets play an important role in their experience with the brands acting with an environmentalist approach. The fact that brands enable an environmentallyfriendly brand experience in their communications with their customers positively shapes the overall brand experience of consumers. Therefore, the fact that brands bring their environmentalist policies to the forefront, provide more information to their customers and increase awareness, emphasize the importance of the environmentalist approach discussed in the study.

\section{Önerilen Atıf/Suggested Citation}

Uzunkaya, T. (2021). Doğaya Saygı İle Çevrecilik Değerlerinin Tüketicilerin Marka Deneyimine Etkisi Üzerine Bir Araştırma, İşletme

Araştırmaları Dergisi, 13 (1), 956-968. 


\section{Giriş}

Hızlanan teknolojik ve endüstriyel gelişim, değişen demografik yapı, insan faaliyetlerinin çevredeki etkisinin büyüklüğünü artırmaktadır. Küresel ısınmanın artması, ozon tabakasının delinmesi, iklim değişikliklerinin yaşanması, biyolojik çeşitlilik azalması, asit yağmuru, suların ve hava kirliliğinin artması gibi çevresel sorunlar, genel olarak, insanlık ve yaşam için küresel bir problem haline gelmiştir (Simão ve Lisboa, 2017: 184). Bu davranışa yönelik dünya çapındaki markalar ya da işletmeler, yeşili benimseyerek; stratejilerini, yeşil pazarlama temelinde oluşturmaktadırlar. Yeşil pazarlama, tüm tüketicilere yönelik eylemlerden oluşmaktadır. İşletmelerin ürün ve hizmetlerinin, çevreye yönelik etkilerini en aza indirme hedefini göstermek için tasarlanmış, farklı pazarlama faaliyetlerini (fiyat, planlama, işlem, üretim, tanıtım ve insan gibi) içermektedir (Groening vd., 2018: 1850).

Artan çevresel kaygılar ve doğayla ilgili yaşanan olumsuz gelişmeler, çevrecilik değerlerinin önemini arttırmaktadır. Çevrenin, insan hayatındaki önemi dikkate alındığında, değer, kişilerin sahip olduğu çevreye ilişkin öz varlıkları ve çevreye duydukları saygıdır. Çevreye ilişkin öz varlıklar, insanların, çevre konusundaki bilgilerini ve bu bilgiler doğrultusunda bilinçli davranışlar sergilemesini ifade eder. Bireylerin, yaşayan tüm canlılara zarar verecek eylemlerden kaçınması, doğaya karşı koruyucu bir tutum sergilemesi ise, doğaya saygıyı içermektedir. İktisadi kalkınma gibi önemli gelişmeler için doğal kaynaklar tahrip edilmemelidir.

Bireylerin çevre bilincine sahip olması, çevreci davranışlar sergilemelerini sağlamaktadır. Bu doğrultuda markaların çevreci yaklaşımı benimseyen politikalar geliştirmeleri, özellikle çevreci yaklaşımı benimseyen tüketicilerin, ürün, alışveriş, hizmet ve tüketim deneyimlerinin toplamı olan, marka deneyimlerinde olumlu bir etki yaratmaktadır.

Araştırmanın amacı, doğaya saygı ve çevreye ilişkin bireyin sahip olduğu değerlerin çevre dostu marka deneyimini ve çevre dostu marka deneyiminin de genel marka deneyimini nasıl etkilediğini ortaya koymaktır. Saari vd., (2017;2020), yaptıkları çalışmalarda, çevre dostluğunu ölçmek için marka deneyimi ölçümü ile ilgili daha önce yapılan araştırmaları genişletmişlerdir. Literatürde, genel marka deneyimine ilişkin çok sayıda çalışma yer alırken; çevre dostu marka deneyimiyle ilgili, az sayıda çalışma bulunmaktadır. Bunun yanı sıra tüketicilerin çevrecilik değerlerine ilişkin ele alınan kavramlar arasında, çevreye ilişkin bireyin sahip olduğu öz varlıklar ve doğaya saygıyla ilgili çalışmalar da kısıtlıdır. Çalışma, markaların çevreci yaklaşımla ilgili etkinliklerini, tüketicilerin, nasıl değerlendirdiğini analiz etmek açısından önemlidir.

$\mathrm{Bu}$ noktadan hareketle araştırmada, Apple ve Samsung akıllı cihaza sahip kullanıcıların, çevrecilik değerlerinin, marka deneyimine etkisi incelenmiştir. Bu kapsamda geliştirilen hipotezler, Apple ve Samsung akıllı cihazlardan birini kullanan tüketiciler üzerinde test edilmiştir. Online anket yöntemiyle elde edilen verileri test etmek için, Yapısal Eşitlik Modellemesi kullanılmıştır.

\section{Kavramsal Çerçeve}

\subsection{Doğaya Saygı ve Çevreye İlişkin Bireysel Öz Varlıklar}

Değer temelli teori, çevresel kaygılar nedeniyle, çevresel tutumların, bir kişinin, daha genel değerler kümesinin sonuçları olduğunu belirtmektedir. Değerler, bir kişinin yaşamına yol gösterici ilkeler olarak hizmet eden, önemli yaşam amaçları veya standartları olarak kavramsallaştırılmıştır (Schultz ve Zelezny, 1999: 255-256).

Genel olarak değerler, davranışın, insanların ve olayların seçimine veya değerlendirilmesine rehberlik eden ve göreceli önem sırasına göre sıralanan, arzu edilen, son durumlara ilişkin inançlara atıfta bulunur. Birleşmiş Milletler Milenyum Deklarasyonunda (Millennium Declaration of the United Nations) yer alan özel değerler, özgürlük, eşitlik, dayanışma, hoşgörü, doğaya saygı ve ortak sorumluluklar olarak ifade edilmiştir (Shepherd vd., 2009: 247).

İnsanların yaşam çizgisini, inandıkları değerler belirlemektedir. İnsanlar, sahip oldukları değerler için mücadele etmektedirler; hatta o değerler uğrunda, ölümü bile göze almaktadırlar. Bireylerin yaşamlarında sahip oldukları değerler ile yaşadıkları çevrenin önemi dikkate alındığında; çevreyi korumanın, insanlara bir değer olarak kazandırılması gerektiğinin önemi daha iyi anlaşılmaktadır (Özhancı ve Yılmaz, 2015: 40). 


\section{T. Uzunkaya 13/1 (2021) 956-968}

Günümüzde tüketiciler, sürdürülebilir tüketimi benimseyerek, çevrenin korunmasına katkıda bulunma eğilimindedirler. Bunun yanı sıra birçok işletme de, tüketicileri, yeşil markalar hakkında eğitmek için çalışmalar yapmaktadır (Prakash vd., 2019: 163). Çevre dostu nitelikler (etik niteliklerin bir alt kümesi), çevreyi korumak (ya da zarar vermemek) için olumlu etkileri olan ürün özellikleridir. Daha önceki çalışmalar, çevre dostu nitelikleri sınıflandırmak için farklı yaklaşımlarda bulunmuşlardır. Örneğin, daha önce yapılmış bir araştırmada, çevre dostu kavramı, "korunan" ve "kutsal" değerler şeklinde ele alınarak incelenmiştir (etik ihlalleri olan bir firmayı boykot etmek gibi). Ayrıca yapılan araştırma, tüketicilerin, etik olmayan unsurları reddettiğini ortaya çıkartmıştır (Paparoidamis ve Tran, 2019: 1549).

İnsanları, sürdürülebilir kalkınmayı desteklemeye motive eden çevre dostu değerler, Birleşmiş Milletlerin sürdürülebilir kalkınma hedefleri tanımında ifade edilen, doğaya saygı kavramını içermektedir. Özellikle tutum ve eylemlerden önce gelen değerler dikkate alındığında; doğaya saygı, sürdürülebilir kalkınma ilkeleri doğrultusunda, doğal kaynakların ve canlı türlerinin yönetimi konusunda, bireyin ihtiyatlı olmaya verdiği önemi, psikolojik bir değer şeklinde kavramsallaştırmaktadır (Saari vd., 2020: 3).

Doğal çevreye odaklanan doğaya saygı, tüm yaşayan canlı türlerinin yönetiminde, ihtiyatlllık anlamına gelmektedir (Shepherd vd., 2013: 1254). Doğaya saygı, bir kişi için önemli çevre dostu değerleri yansıtırken; çevreye ilişkin bireysel öz varlıklar, kişinin çevre sorunlarıyla başa çıkma yeteneğine ilişkin kendi değerlemesini ifade etmektedir. Çevreye ilişkin bireyin sahip olduğu öz varlıklar, insanların çevresel sorunlar hakkındaki bilgisini ve kişisel yaşamlarında, çevresel sorunları ele alma deneyimlerini ifade etmektedir (Saari vd., 2020: 3).

Sonenshein vd., (2014: 9) çalışmalarında, benliğin değerlendirilmesinde yer alan çabaya (buradaki benlik, bireyin kendisi hakkındaki algıları, düşünceleri ve duyguları olarak ya da bir kişi olarak kendisini tanımlanmaktadır) atıfta bulunarak, iki temel yapıyı geliştirmişlerdir; öz varlıklar ve kendinden şüphe etme. İlk kavram, bir konuda harekete geçmede psikolojik yeteneklerle ilgili öz değerlendirmelere ve ikincisi, konu ile ilgili performans açısından benliği olumsuz olarak değerlendiren öz değerlendirmelere odaklanır.

Sonenshein vd., (2014: 20-21), destek sorunlarıla ilgili olarak, destekçilerin öz varlıklarını değerlendirdiklerini, bunu sahip oldukları yetenekleri belirleme ve olumlu olarak değerlendirme yolları olarak tanımladıklarını ortaya koymuşlardır. Yazarlar, öz varlıkları; değer varlıkları, deneyim varlıkları ve bilgi varlıkları olarak sınıflandırmıştır. Değer varlıkları, sorun destekçisi olmak için, doğru değerlere sahip olmaktır; değerler, etik veya daha fazla konuyla ilgili olabilir. Etik ise, genellikle doğru şeyi yapmaya odaklanacak şekilde kendilerini değerlendiren, sorun destekçilerini içermektedir. Bilgi varlıkları, bireyin, ilgili sorunla alakalı bilgi kapasitesi ve uygunluğu hakkındaki, olumlu öz değerlendirmesini yansıtmaktadır. Deneyim varlıkları ise, ilgili konuyu desteklemede, anlamlı bir uygulama kazanmış biri olarak, benliğin değerlendirilmesini içermektedir.

Doğaya saygı ve çevresel öz varlıklar, hangi bilgilerin bilişsel olarak bireyler için en erişilebilir olduğu, insanların bir durumun farklı yönlerini (örneğin, bir satın alma durumunda) nasıl değerlendirdiği ve hangi alternatif satın alma türlerini dikkate aldığı gibi, kişisel eko-davranışsal niyetlerini açıklayan, önemli öncüller olarak düşünülebilir. Bireyler, genel sürdürülebilir kalkınma değerleriyle ilişkili olan doğaya karşı, belirli bir düzeyde saygıya sahiptirler ve sahip oldukları öz varlıkların, çevreyi korumaya ne kadar yardımcı olabileceğine dair bir görüşe sahiptirler (Saari vd., 2020: 3).

\subsection{Marka Deneyimi ve Çevre Dostluğu}

Deneyim, müşterilerin fiziksel, rasyonel, sosyal ve derinden bağlantı kurmasını sağlayarak; tüketim etkileşimini, anlamlı ve gerçek kılmaktadır. Marka deneyimi, tüketicinin, ürün/hizmetleri tüketmek için belirli niyetlerle, markayla etkileşim kurduğunda ve iş birliği yaptığında, sahip olduğu; ürün, alışveriş, hizmet ve tüketim deneyimlerinin toplamıdır (Arya vd., 2019: 143).

Bir marka, genellikle, marka deneyiminden kaynaklanan, hem işlevsel hem de deneyimsel değerler sağlamaktadır. Marka deneyimi, tüketicilerin, marka ve işletmeyle olan satın alma ve tüketim deneyimlerini, bunun yanı sıra tüketici olmayanlar üzerindeki marka etkisini ifade etmektedir. Deneyimlerin, duyusal (duyularımıza rağmen hissedilen deneyimlerle ilgili), duygusal (duygusal etkileşimlerle ilgili), davranışsal (deneyimden zevk alan tüketiciler tarafından alınan eylemlerle ilgili) ve entelektüel (deneyimin ortaya 


\section{T. Uzunkaya 13/1 (2021) 956-968}

çıkardığı rasyonel düşünceler) gibi farklı bileşenleri, satın alma karar sürecinde ortaya çıkabilir (Prentice vd., 2019: 51).

Duyusal marka deneyimi, görme, işitme, koklama, tat alma ve dokunma duyuları aracılığıyla ortaya çıkmaktadır. Duygusal marka deneyimi, tüketicinin duygusal tepkisini; entelektüel marka deneyimi, bilişsel uyarımı; davranışsal ise, marka deneyiminin belirli davranışları nasıl tetiklediğini ifade etmektedir (Oh vd., 2020: 2).

Tüketiciler, yalnızca ürün ve hizmetleri değil aynı zamanda markaları da satın almaktadırlar. Markalarla duygusal ilişkiler kurarlar; kişiliklerini ve sosyal benliklerini ifade etmek için de markaları kullanırlar. Dolayısıyla, markaların sağladığı deneyimler, markayla ilgili birçok uyaranın, tüketicide uyandırdığı hislere, duygulara, sezgilere ve davranışlara hitap eden deneyimler yaratarak; işletmeler arasındaki temel farklılaşma biçimlerinden biri olarak sunulmuştur (Pina ve Dias, 2021: 99).

İyi bir marka deneyimi, aşinalığın yanı sıra markayı anlama, zevk alma, geliştirme ve teşvik etmeyi de önemli derece etkilemektedir (Keng vd., 2013: 250). Ayrıca, marka yönetimi araştırmacıları, marka deneyiminin; marka tutumunun, satın alma niyetinin, marka güveninin, tüketici-marka ilişkisinin, marka sadakatinin ve marka değerinin öncüsü işlevine sahip olduğunu doğrulamışlardır (Kim ve Song, 2019: 257). Brakus vd., (2009: 65), yaptıkları çalışmayla, marka deneyiminin davranışsal bir etkiye sahip olduğunu ifade etmektedirler. Araştırmacılar, marka deneyiminin, marka kişiliği aracılığıyla marka tatminini ve marka sadakatini doğrudan ve dolaylı olarak etkilediğini ortaya çıartmışlardır. Tüketicinin marka deneyimi, satın alma sürecinden, reklam, iletişim ve web sitesi ziyaretine dayalı dolaylı deneyimlere kadar her şeyi içermektedir (Jeong vd., 2017: 1206).

Yapılan çalışmalara göre, marka deneyimi, hafızada saklı olma, güç ve süreye göre değişebilmektedir. Örneğin, bazı marka deneyimleri diğerlerinden daha olumlu ya da olumsuz olabilmekte veya diğerlerinden daha güçlü ya da daha etkili olarak algılanabilmektedir. Bununla birlikte marka deneyimleri, kasıtlı olarak veya kendiliğinden ortaya çıkabilir ve zaman içinde, sürdürülebilir ya da kısa ömürlü olabilir. Bir süre boyunca tüketicinin hafızasında saklı olan marka deneyimi ise, tüketicinin marka hakkında nasıl hissettiğini etkileyebilmektedir (Ramaseshan ve Stein, 2014: 667).

Son yıllarda artan çevresel sorunlar nedeniyle, markaların çevreci yaklaşımı benimsemeleri, tüketicilerin duygu ve düşüncelerini, markaya yönelik tutumlarını, satın alma davranışlarını etkileyebilmektedir. Tüketiciler, çevre dostu ürünlere yönelik talep aracılı̆̆ıyla, çevre için artan endişelerini yönlendirmektedirler. $\mathrm{Bu}$ "yeşile yönelim" hareketi, daha sağlıklı bir şekilde yaşama konusundaki yoğun farkındalığı nedeniyle dünya çapında genişlemiştir (Suki, 2016: 2894).

Çevre dostu, doğal kaynakları tamamen kullanmayan ya da yok etmeyen yöntemleri içerdiğinden dolayı çevreye zararlı olmayan ve sürdürülebilir olarak da ifade edilmektedir (Campbell vd., 2015: 21-22). Yeşil bir marka, çevresel kaygıları artan tüketicilerde, olumlu bir etki yaratmasıyla ve olumsuz çevresel etkileri azaltmasıyla ilişkili bir dizi fayda ve özellikleri gerektirmektedir (Suki, 2016: 2894).

Yenilenemeyen doğal kaynak ve enerji kullanımının, çevre dostu olmayan üretim sürecinin ve çevresel felaketlerin sebep olduğu çevresel sorunların ciddiyetini kabul eden ve her geçen gün sayıları artan bireyler, çevre sorunlarının ve kaynakların, sınırlı olduğunun farkındadırlar. Bu çevre bilinci, insanlara, çevre dostu faaliyetlere karşı olumlu bir tutum kazandırmakta ve insanları günlük yaşamlarında daha sık çevreci davranışlarda bulunmaya teşvik etmektedir. Bu bireyler, güçlü bir çevresel tutuma sahip olmanın yanı sıra çevre dostu bir şekilde davranmak için fırsat aramaktadırlar (Han vd., 2011: 346).

Yapılan çalışmalara göre, çevre dostu markaların farkındalı̆̆ı ve bu markaları satın alma niyeti, çevreyi koruma arzusu ve çevre dostu ürünlere olan inançlar tarafından etkilenmektedir. Tüketicilerin çevre kaygıları, çevrenin korunmasına katılımlarını yansıtmaktadır (Prakash ve Pathak, 2017: 387). Bununla birlikte, tüketicilerin marka tatmini ve marka sadakatinin, marka tarafından temsil edilen çevre dostu ve yeşil değerlerle ilişkilendirilebileceğine dair birçok gösterge bulunmaktadır (Saari vd., 2017: 2).

Çevresel sürdürülebilirlik, her geçen gün önemi artan bir konu olduğundan dolayı tüketicilerin sürdürülebilirliğe katılımının arttığı varsayılmaktadır. Bunun yanı sıra tüketiciler sürdürülebilir ürünleri 


\section{T. Uzunkaya 13/1 (2021) 956-968}

deneyimlediklerinde, daha fazla ürün bilgisi elde etmektedirler ve bu nedenle, marka iletişimini daha az deneyime sahip olanlardan, daha iyi anlamaktadırlar (Kumagai ve Nagasawa, 2020: 4).

Markalar, çevre dostu yaklaşımları benimsemenin ve uygulamanın yaratacağı olumlu etkiler konusunda, tüketicileri bilinçlendirmelidirler. Ayrıca çevreci yaklaşım konusunda yaptıkları faaliyetleri, tüketicilerle olan iletişimlerinde ön plana çıkarmaları, çevre dostu marka deneyimi açısından oldukça önemlidir. Bu bağlamda araştırmada iki tür marka deneyimi kavramından söz edilmektedir; genel marka deneyimi ve çevre dostu marka deneyimi. Genel marka deneyimi, Brakus vd., (2009), tarafından önerilen ve tanımlanan dört farklı boyutla ele aldıkları, tüketicilerin, algılara dayalı markalarla sahip oldukları deneyimleri ifade etmektedir. Söz konusu dört farklı boyut duygusal, davranışsal, entelektüel ve duyusaldır. Buna paralel olarak, Saari vd., (2017: 7), çevre dostu marka deneyiminin boyutlarını; eko-entelektüel, eko-duyusal, eko-duygusal ve ekodavranışsal düzeyler olarak ele almışlardır.

Tüketici, otomobil, ev aletleri ya da pahalı tüketici elektroniği gibi önemli satın alımlara karar vermesi gerektiğinde, eko-entelektüel düzeyde ürün ya da markalarla ilgili gerçekçi bilgileri dikkate almaktadır. Bu bilgi çevresel performansın (örneğin, enerji tasarrufu), üretimin (malzemeler, kimyasallar, geri dönüştürülebilirlik ya da tamir edilebilme özelliği) ve ikinci el ürünlerin mevcudiyetinin detaylarını içermektedir. Sürdürülebilir ve çevre dostu ürünlerin görünümü ve hissi, ana modellerden farklı olabileceğinden, eko-duyusal seviye, çevre dostu ürünler için kritiktir. Çevre dostu ürünler genellikle düşük etkili veya geri dönüştürülmüş malzemelerden üretilir ve malzemeler, ürünlerin tüm yaşam döngülerinin etkilerini dikkate alan eko-tasarım ilkelerini izleyerek minimuma indirilir. Eko-duygusal düzey, çevre dostu olmanın genel duygusal deneyimleriyle ilişkilidir. Tüketiciler, çevresel sorunların çözümüne yararlı bir şekilde ortak olduklarında, olumlu duygulara sahip olma eğilimindedirler. Örneğin, tüketiciler, iyi bir çevresel nedeni seçimleriyle desteklediklerini hissettiklerinde, kendinden memnun olma (kişisel tatmin) duygularını oluşabilir. Eko-davranışsal düzey ise, tüketicilerin sürdürülebilir bir şekilde hareket etmelerine ve tüketmelerine yardımcı olmak için, bir markayı nasıl değerlendirdikleriyle ilişkilidir. Çevre dostu olarak algılanan bir marka, tüketicilerin ekolojik açıdan bilinçli bir yaşam tarzı izlemelerinde ve tüketim alışkanlıklarında, daha sürdürülebilir olmalarını desteklemektedir. Bir marka sürdürülebilir ve çevreye duyarlı olarak algılandığında; çevre bilincindeki tüketiciler, markaları, kendi kimliklerini oluşturmak ve çevre yanlısı öz kimliklerini güçlendirmek için kullanırlar (Saari vd., 2017: 7-8).

Son yıllarda tüketiciler, çevre sorunları konusunda daha bilinçli bir tutum sergilemektedir. Çevreye zarar vermeyen ya da zararı en aza indiren, sürdürülebilir üretim ve tüketimi desteklemektedirler. Tüketicilerin çevreci yaklaşım sergilemelerinde, sahip olduğu değerler, önemli rol oynamaktadır. Bu değerlerden ilki, tüketicilerin, gelecekte yaşanabilecek çevresel sorunlar konusunda, çevreye karşı korumacı bir tutum sergilemesini ifade eden, doğaya duyduğu saygıyla ilgilidir. İkincisi ise, çevresel sorunlar konusunda, tüketicinin bilgi birikimine sahip olması ve çevresel sorunlara olan yaklaşımlarını, bu sorunlar karşısındaki eylemlerini ifade eden, bireyin sahip olduğu öz varlıklardır. Tüketiciler sahip oldukları değerlerle, çevre dostu bir tutum sergilemenin yanı sıra çevre dostu bir şekilde davranmak için fırsat aramaktadırlar. Dolayısıyla, çevre dostu ürünleri deneyimlemeyi tercih edeceklerdir. Çevre dostu marka deneyiminin, genel marka deneyimine etkisinin olumlu yönde olduğu araştırmalarla desteklenmiştir. İşletmeler, her geçen gün çevre konusunda bilinçlenen tüketicilere, sahip olduğu çevresel değerleri de dikkate alarak; çevre dostu marka deneyimi sağlamaları, işletmelere olumlu yönde katkı sağlayacaktır.

\section{Yöntem}

\subsection{Araştırmanın Amacı, Kavramsal Modeli ve Kapsamı}

Doğal kaynakların tahrip edilmesine yönelik insanların farkındalığı her geçen gün artmaktadır. Ancak çevresel dönüşümü yönetmek için bireysel eylemler yeterli değildir; düzenleyici kurum ve kuruluşların, tüketicilerin, sivil toplum kuruluşlarının ve diğer paydaşların ortak çabalarına dayalı, güçlü bir ekosistemin kurulması da gereklidir (Blasi vd., 2020: 2).

Artan çevresel sorunları azaltmaya yardımcı olan, çevreye en az zarar veren ürünler ve çevresel sorunlarla ilgili, tüketicilerin tutumlarını, inançlarını ve davranışlarını anlamak üzerine artan bir odaklanma söz konusudur (Trivedi vd., 2018: 11). Araştırmada da, çevreci politikalarını ön plana çıkarmaya çalışan, Apple ve Samsung şirketleri baz alınmıştır. 


\section{T. Uzunkaya 13/1 (2021) 956-968}

Apple'ın bütün ofisleri, mağazaları ve data merkezleri, \%100 yenilenebilir enerji ile çalışmaktadır. Cıva, bromlu alev geciktiriciler, PVC ve berilyum gibi zararlı kimyasalları ürün kartelalarından çıkarmıştır. Çin'de 400.000 hektarın üzerinde orman, Apple'ın çabalarıyla, daha gelişmiş bir yönetim tarafından kontrol edilmektedir. Ürünlerini daha az enerji harcayacak şekilde tasarlamaktadır. Daisy'i yaratan Apple, iPhone'daki tungsten ve nadir bulunan toprak elementleri gibi malzemeleri kurtarmaktadır (https://www.apple.com/tr/). Zararlı kimyasalları ürünlerinden uzak tutmak amacıyla, Çevresel Test Laboratuvarı'nı kurmuştur. Toksikoloji uzmanları bu laboratuvarda malzemeleri detaylı bir şekilde inceleyerek, zararlı bileşenler içerip içermediklerine bakmaktadır. Kullanıcıların dokunduğu malzemelerle, ciltleri arasındaki etkileşimi taklit etmek için laboratuvarda yapay ter dahi ürettikleri belirtilmektedir (https://www.apple.com/tr/).

Samsung, son dört yılda 2.400 adet cep telefonu atığının tekrar kullanılmasının sağlandığını belirtmektedir. Toplanan cep telefonlarının; altın, gümüş ve bronz gibi önemli kaynakları geri kazanmak için, geri dönüşüm konusunda uzmanlaşmış şirketlere gönderilmekte ve hatta bazı Galaxy telefonların ileri dönüştürme projesiyle bağlantılı olarak, oftalmoskop destek işi gibi kurumsal sosyal sorumluluk faaliyetlerinde kullanıldığı ifade edilmektedir. 20 Mart 2019 'da 38 üretim tesisinin (7 yurtiçi ve 31 uluslararası) yanı sıra Samsung'un Suwon tesisi ve satış ofisleri sera gazını azaltmak ve güç kısıntıları ile uğraşan bölgeler için umut ışığı olmak üzere, "Küresel Köy Işıkları Kapalı" kampanyasına katılmıştır. Işıkları söndürme kampanyasından tasarruf edilen enerji maliyetlerini ve çalışan bağışlarını kullanarak 1000 güneş enerjili LED model kiti hazırlamışlardır. Bu kitler Samsung çalışanlarınca monte edilerek, Vietnam'ım Son La ilindeki Huoi Do - Chieng Noi köyünün halkına bağışlanmıştır (https://www.samsung.com/tr/).

Sorumlu iş birliğinin (RBA) bir üyesi olarak Samsung Electronics, iş yerlerini ve tedarikçilerini yönetmenin bir parçası olarak RBA İş Etiği Kurallarına ve çevre, sağlık ve güvenlik ve işgücü standartlarına uyum gösterdiğini ifade etmektedir. Samsung, temiz enerjiye global geçiş sürecini hızlandırmak için politikalar geliştirmeye ve en iyi uygulamaları paylaşmaya yönelik küresel bir forum olan, Temiz Enerji Bakanlar Zirvesine imza atan bir kuruluş olarak, küresel tesislerinden sera gazı emisyon yoğunluğunu (satışlara göre normalleştirilmiş) 2008' deki seviyeye göre, yüzde 70 azaltmayı ve tüm küresel üretim sahalarının ISO 50001 sertifikasını muhafaza edeceğini taahhüt etmektedir. Samsung Electronics, 2010'dan 2016 yılına kadar arka arkaya yedi yıl boyunca iklim değişikliği müdahalesine ilişkin bilgileri açıklaması nedeniyle en üst düzey olan, Liderlik A'ya layık görüldüğünü belirtmektedir (https://www.samsung.com/tr/).

Araştırmanın amacı, doğaya saygı ve çevreye ilişkin bireyin sahip olduğu değerlerin çevre dostu marka deneyimini; çevre dostu marka deneyiminin de genel marka deneyimini, nasıl etkilediğini ortaya koymaktır. Saari vd., (2017;2020), yaptıkları çalışmalarla, çevreci yaklaşımları ölçmek için marka deneyimi ölçümü ile ilgili daha önce yapılan araştırmaları genişletmişlerdir. Literatürde, genel marka deneyimine ilişkin çok sayıda çalışma yer alırken; çevre dostu marka deneyimiyle ilgili çalışmalar az sayıdadır. Bunun yanı sıra tüketicilerin çevrecilik değerlerine ilişkin ele alınan kavramlar arasında, çevreye ilişkin bireyin sahip olduğu öz varlıklar ve doğaya saygı ile ilgili çalışmalarda kısıtlıdır. Çalışma, markaların çevreci yaklaşımla ilgili etkinliklerini, tüketicilerin nasıl değerlendirdiğini analiz etmek açısından önemlidir.

Tüketicilerin çevreye ilişkin kaygıları ve çevreyi korumaya yönelik istekleri, tüketicileri, çevreci davranışlarda bulunmaya teşvik etmektedir. Saari vd.'nin (2020) yaptığı çalışmada, tüketicilerin doğaya saygıları, çevresel marka deneyimini olumlu yönde etkilerken; tüketicilerin sahip oldukları öz varlıklar, çevresel marka deneyimini olumlu yönde etkilememektedir. Yazarlar, çevre dostu marka deneyiminin genel marka deneyimine etkisini ise anlamlı bulmuşlardır. Yapılan araştırmada analiz sonucunda, çevresel marka deneyiminin, genel marka deneyimine etkisini anlamlı bularak, önceki çalışmayı desteklemektedir. Ancak kullanıcıların çevreye ilişkin sahip olduğu öz varlıklar, çevre dostu marka deneyimini olumlu yönde etkilerken; doğaya saygı çevre dostu marka deneyimini olumlu yönde etkilememektedir.

Araştırmanın modeli, Saari vd.'nin (2020: 4) yaptığı çalı̧̧madan yararlanılarak oluşturulmuştur. Adı geçen yazarların modeli kullanılmış olmakla birlikte, yukarıda belirtilen farklılıklar ışığında söz konusu kavramsal model ile analizler gerçekleştirilmiştir. Araştırmanın kavramsal modelinde, Şekil 1'de gösterildiği üzere, model dört değişkenden oluşmaktadır. Bu değişkenler, doğaya saygı, çevreye ilişkin bireyin sahip olduğu öz varlılar, çevre dostu marka deneyimi ve genel marka deneyimidir. 


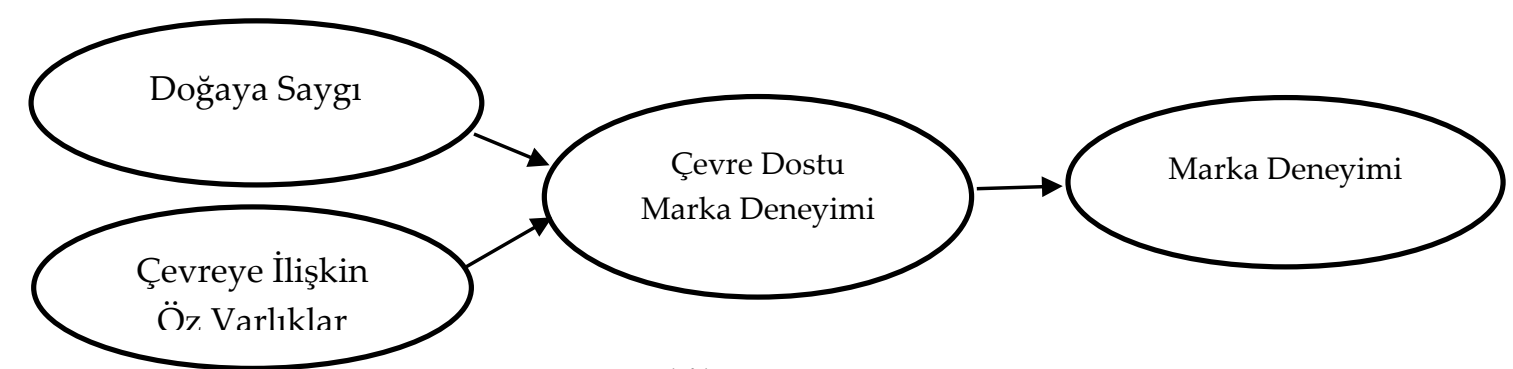

Şekil 1. Araştırma Modeli

Doğaya saygı ve bireylerin sahip olduğu çevresel öz varlıkların, çevre dostu marka deneyimini, çevre dostu marka deneyiminin de genel marka deneyimini nasıl etkilediğine yönelik yapılan çalışmanın evrenini, Apple ve Samsung akıllı cihaz kullanan, 18 yaş ve üzeri tüketiciler oluşturmaktadır. Araştırmanın örneklemi ise, 18 yaş ve üstü, söz konusu iki marka akıllı cihazlardan birini kullanan tüketicilerdir. Evrene ulaşılmasının pratikte mümkün olmadığı dikkate alınarak, örnekleme yapılmıştır. Evren ile ilgili bir genelleme yapma hedefi öngörülmediğinden, tesadüfi olmayan örnekleme yöntemlerinden kolayda örnekleme yöntemi kullanılmıştır. Örnek büyüklüğünü belirlemek üzere evrenin iki şıklı evrene dönüştürülebileceği dikkate alınarak, aşağıda varsayılan güvenlik düzeyi ve tolerans ile örneklem büyüklüğü hesaplanmıştır. Aşağıda yer alan formülde belirtildiği üzere evren, çevreci yaklaşımdan etkilenen ve etkilenmeyen olmak üzere iki şıklı evren olarak değerlendirilmiş; $p$ 'nin bilinmediği durumlarda iki şıklı evrenlerde maksimum varyansı veren 0,5 değeri kullanılmıştır.

Örnek büyüklüğü şu şekilde belirlenmiştir (Yükselen, 2017: 67):

p: markanın çevreci yaklaşımından etkilenen tüketicilerin 0ranı $(0,5)$

q: $1-\mathrm{p}(0,5)$

Z: Güvenlik düzeyinde normal değer ( $\% 95,5^{\prime}$ te \pm 2$)$

e: Tölerans düzeyi $( \pm \% 4)$

$\mathrm{n}=\mathrm{p}^{*} \mathrm{q} *(\mathrm{Z} / \mathrm{e})^{2}=0,5 * 0,5 *(2 / 0,04)^{2}=302$

Veri toplama yöntemi olarak online anket yöntemi kullanılmış ve bu amaçla hazırlanan anket formu cevaplayıcılara doldurtulmuştur.

\subsection{Hipotezler}

Günümüzde tüketiciler, sürdürülebilir tüketimi benimseyerek, çevrenin korunmasına katkıda bulunma eğilimindedirler (Prakash vd., 2019: 163). Araştırmacılar, değerlerin, tutum ve davranışları etkilediğini yaptıkları çalışmalarla ortaya çıkartmışlardır (Shepherd vd., 2009: 254). Bununla birlikte daha önce yapılan çalışmalar, tüketicilerin kesinlikle etik olmayan unsurları reddettiğini ortaya çıkartmıştır (Paparoidamis ve Tran, 2019: 1549).

Çevre bilinci, insanlara, çevre dostu faaliyetlere karşı olumlu bir tutum kazandırmakta ve insanları günlük yaşamlarında daha sık çevreci davranışlarda bulunmaya teşvik etmektedir. Bu bireyler, güçlü bir çevresel tutuma sahip olmanın yanı sıra çevre dostu bir şekilde davranmak için fırsat aramaktadırlar (Han vd., 2011: 346).

Yapılan çalışmalara göre, çevre dostu markaların farkındalığı ve bu markaları satın alma niyeti, çevreyi koruma arzusu ve çevre dostu ürünlere olan inançlar tarafından etkilenmektedir. Tüketicilerin çevre kaygıları, çevrenin korunmasına katılımlarını yansıtmaktadır (Prakash ve Pathak, 2017: 387). Ayrıca, tüketicilerin marka tatmini ve marka sadakatinin, marka tarafından temsil edilen çevre dostu ve yeşil değerlerle ilişkilendirilebileceğine dair birçok gösterge bulunmaktadır (Saari vd., 2017: 2).

Saari vd., (2017) tüketicilerin marka deneyimlerinde, çevre dostluğu yaklaşımını nasıl algıladıklarını, ölçmeyi amaçlamışlardır. Bu amaçla, veriler, Hindistan ve Finlandiya'daki akıllı cihaz kullanan tüketicilerden oluşmaktadır. Tüketicilerin Apple, Samsung ve Nokia markalarıyla ilgili cevaplarından oluşan ampirik 


\section{T. Uzunkaya 13/1 (2021) 956-968}

veriler, tüketicilerin genel marka deneyimlerinde, benzersiz bir çevre boyutu olduğunu ve Hindistan ve Finlandiya tüketicileri için genelleştirilebilir olduğunu doğrulamışlardır.

Saari vd., (2020) yaptıkları bir başka çalışmada, tüketicilerin doğaya saygısının, çevresel marka deneyimini olumlu yönde etkilediğini; sahip oldukları öz varlıkların, çevresel marka deneyimini olumlu yönde etkilemediğini bulmuşlardır. Bununla birlikte araştırmacılar, çevresel marka deneyiminin, genel marka deneyimine etkisinin olumlu yönde olduğunu ortaya çıkarmışlardır.

Bu noktadan hareketle araştırmanın hipotezleri şu şekilde belirlenmiştir:

H1. Tüketicilerin doğaya saygısı, çevre dostu marka deneyimlerini olumlu yönde etkilemektedir.

H2. Çevreye ilişkin bireyin sahip olduğu öz varlıklar, çevre dostu marka deneyimlerini olumlu yönde etkilemektedir.

H3. Tüketicilerin çevre dostu marka deneyimleri, genel marka deneyimlerini olumlu yönde etkilemektedir.

\section{3. Ölçüm Modeli}

Uyum iyiliği istatistikleri, modelin kabul edilip edilmeyeceği konusunda birtakım kabul edilebilir sınır değerler kullanılarak yorumlanmaktadır. Başka bir ifadeyle, analiz sonucunda ortaya çıkan uyum istatistiklerinin, belirli değerlerin üstünde ya da altında olması istenmektedir. $\mathrm{X}^{2}$ değerinin serbestlik derecesine bölünmesiyle, bu oranın iki ya da altında olması, modelin iyi bir model olduğunu; beş ya da altında bir değer alması ise, modelin kabul edilebilir bir uyum iyiliğine sahip olduğunu göstermektedir. Bu iki değerin haricinde birçok uyum iyiliği istatistiği vardır. Bunlardan ilk üçü olan, GFI (Goodness of Fit Index), AGFI (Adjusted Goodness of Fit Index) ve CFI (Comparative Fit Index) değerlerinin, 0,90'dan büyük olması, kabul edilebilir bir uyum iyiliği değerinin; 0,95'ten büyük olmaları ise, iyi bir uyum iyiliği değerinin göstergesi olarak kabul edilmektedir. RMSEA (Root Mean Square Error of Approximation) ve RMR (Root Mean Square Residual) değerlerinin ise, 0,05'in altında olması, iyi bir fit değerini; 0,08' in altında olması, kabul edilebilir bir uyum iyiliği değerini ifade etmektedir (Şimşek, 2007: 13-14).

\subsection{Verilerin Analizi ve Bulgular}

Araştırmanın kavramsal modeli çerçevesinde Lisrel Yapısal Eşitlik Modelli kullanılarak önce ölçme modeli test edilmiş olup, örtük değişkenler ve gözlenen değişkenlerden oluşan yapı analiz edilmiştir. Ölçüm modeline ilişkin standart uyum ölçütleri ile hesaplanan uyum değerleri Tablo 1'de gösterilmektedir:

Tablo1. Ölçüm Modelinin Uyum Değerleri ve Standart Uyum İyiliği Değerleri

\begin{tabular}{|c|c|c|c|c|}
\hline İndeks & $\begin{array}{c}\text { İyi Uyum } \\
\text { Değerleri }\end{array}$ & $\begin{array}{c}\text { Kabul Edilebilir } \\
\text { Uyum Değerleri }\end{array}$ & $\begin{array}{c}\text { Ulaşılan Uyum } \\
\text { Değerleri }\end{array}$ & Uyum Durumu \\
\hline $\mathbf{x}^{2} / \mathbf{s d}$ & $\mathrm{x}^{2} / \mathrm{sd} \leq 2$ & $\mathrm{x}^{2} / \mathrm{sd} \leq 5$ & 2,01 & Kabul Edilebilir \\
\hline RMSEA & RMSEA $<0.05$ & RMSEA $<0.08$ & 0,058 & Kabul Edilebilir \\
\hline RMR & RMR $<0,05$ & RMR $<0,08$ & 0,04 & Iyi Uyum \\
\hline CFI & CFI $>0,95$ & CFI $>0.90$ & 0,95 & Kabul Edilebilir \\
\hline GFI & GFI $>0,95$ & GFI $>0,90$ & 0,89 & Kabul Edilebilir \\
\hline AGFI & AGFI $>0,95$ & AGFI $>0,90$ & 0,85 & Kabul Edilebilir \\
\hline
\end{tabular}

Şekil 1'de gösterilen kavramsal model, doğrulayıcı faktör analizi ile test edilmiş olup değişkenlerin modelde kullanılan kısaltma adları şu şekildedir: DS ve Ds, doğaya saygı; COV ve Cov, çevresel öz varlıklar; DYGSLMD ve Dygsl, duygusal marka deneyimi; DYUSLMD ve Dyusl, duyusal marka deneyimi; DAVMD ve Davmd, davranışsal marka deneyimi; ENTMD ve Entmd, entelektüel marka deneyimi; CMD ve Cmd, çevresel marka deneyimi. (Genel genel marka deneyimi bileşenleri; duygusal, duyusal, entelektüel ve davranışsal). Uyum iyiliği değerleri kabul edilebilir sınırlar içinde çıan Şekil 2'de, doğrulayıcı faktör analizi sonuçları gösterilmiştir. Bu sonuçlara göre modeli oluşturan doğaya saygı, çevreye ilişkin öz varlıklar, çevre dostu marka deneyimi ve marka deneyimi değişkenlerinin, bu değişkenleri ifade eden soru maddeleriyle bütünlük oluşturduğu ve ilişkilerin testine uygun olduğu görülmektedir. 


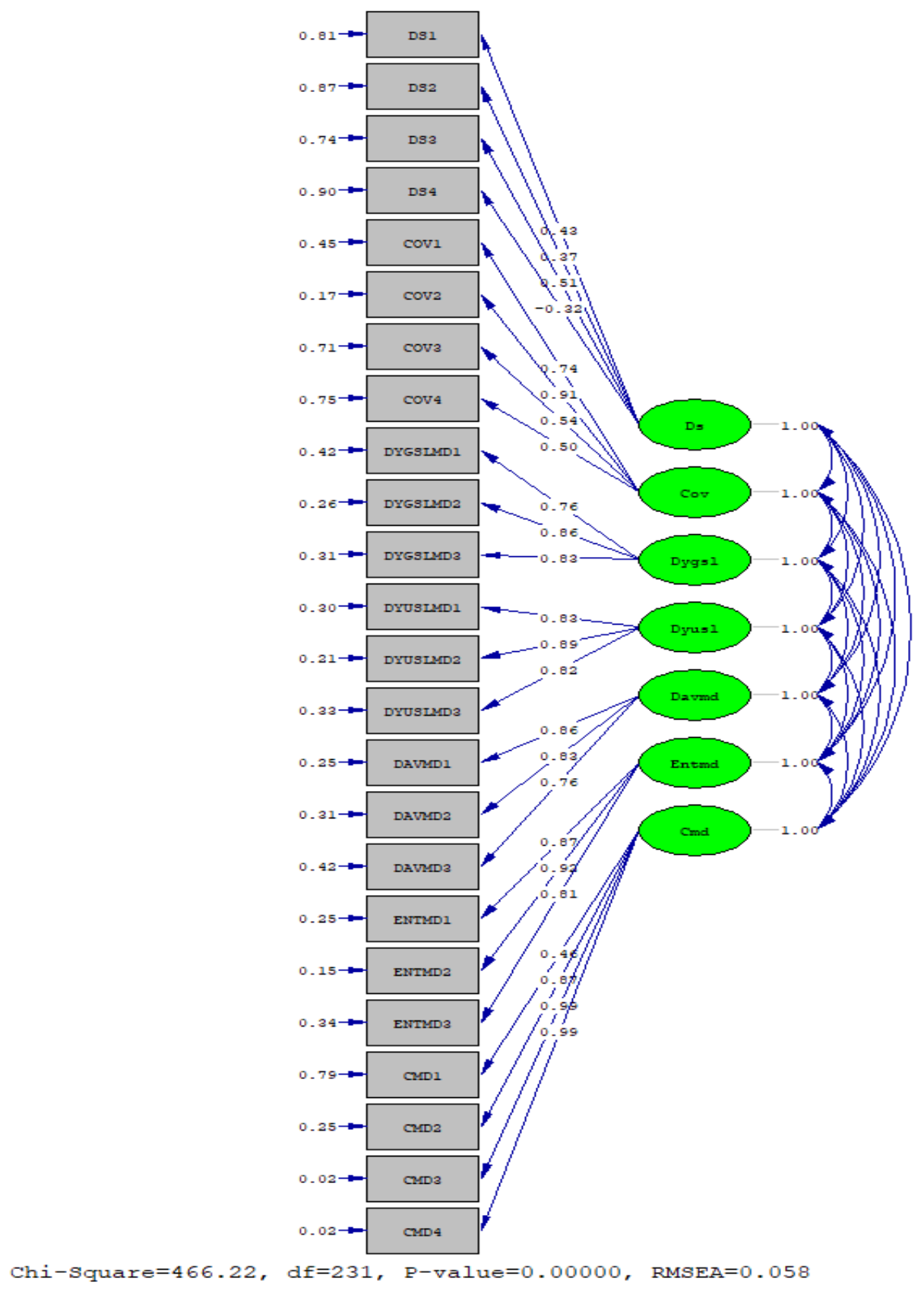

Şekil 2. Ölçme Modelinin Testi Anlamlılık Sonuçları

Modelde yer alan yapısal ilişkiler, bu ilişkilere ait standardize etki değerleri, ( $\mathrm{p} \leq \% 5$ önem derecesinde anlamlı çıan) $t$ değerleri ve açıklanan varyans değerleri Tablo 2'de yer almaktadır. Kavramsal modelin yapısal eşitlik modeli testinin sonuçları standart çözüm değerleri olarak Şekil 3'te gösterilmiş olup, uyum iyiliği değerleri kabul edilebilir sınırlar içinde çıkmıştır. 
T. Uzunkaya 13/1 (2021) 956-968

Tablo2. Yapısal Modelden Elde Edilen Yapısal İlişkilere Ait Sonuçlar

\begin{tabular}{|c|c|c|c|}
\hline Yapısal Eşitlikler & $\begin{array}{c}\text { Standardize } \\
\text { Etki }\end{array}$ & t- değeri & $\begin{array}{c}\text { Açıklanan } \\
\text { Varyans }\left(\mathbf{R}^{2}\right)\end{array}$ \\
\hline Doğaya Sayg1*Çevresel Marka Değeri & 0,080 & 1,15 & 0,0084 \\
\hline Çevresel Öz Varlıklar*Çevresel Marka Deneyimi & 0,066 & 3,69 & 0,059 \\
\hline Çevresel Marka Deneyimi*Genel Marka Deneyimi & 0,075 & 8,56 & 0,41 \\
\hline
\end{tabular}

$\mathbf{x}^{2} / \mathbf{s d}=2,27, \mathbf{R M S E A}=0,065, \mathbf{R M R}=0,054, \mathbf{C F I}=0,93, \mathbf{G F I}=0,87, \mathbf{A G F I}=0,84$

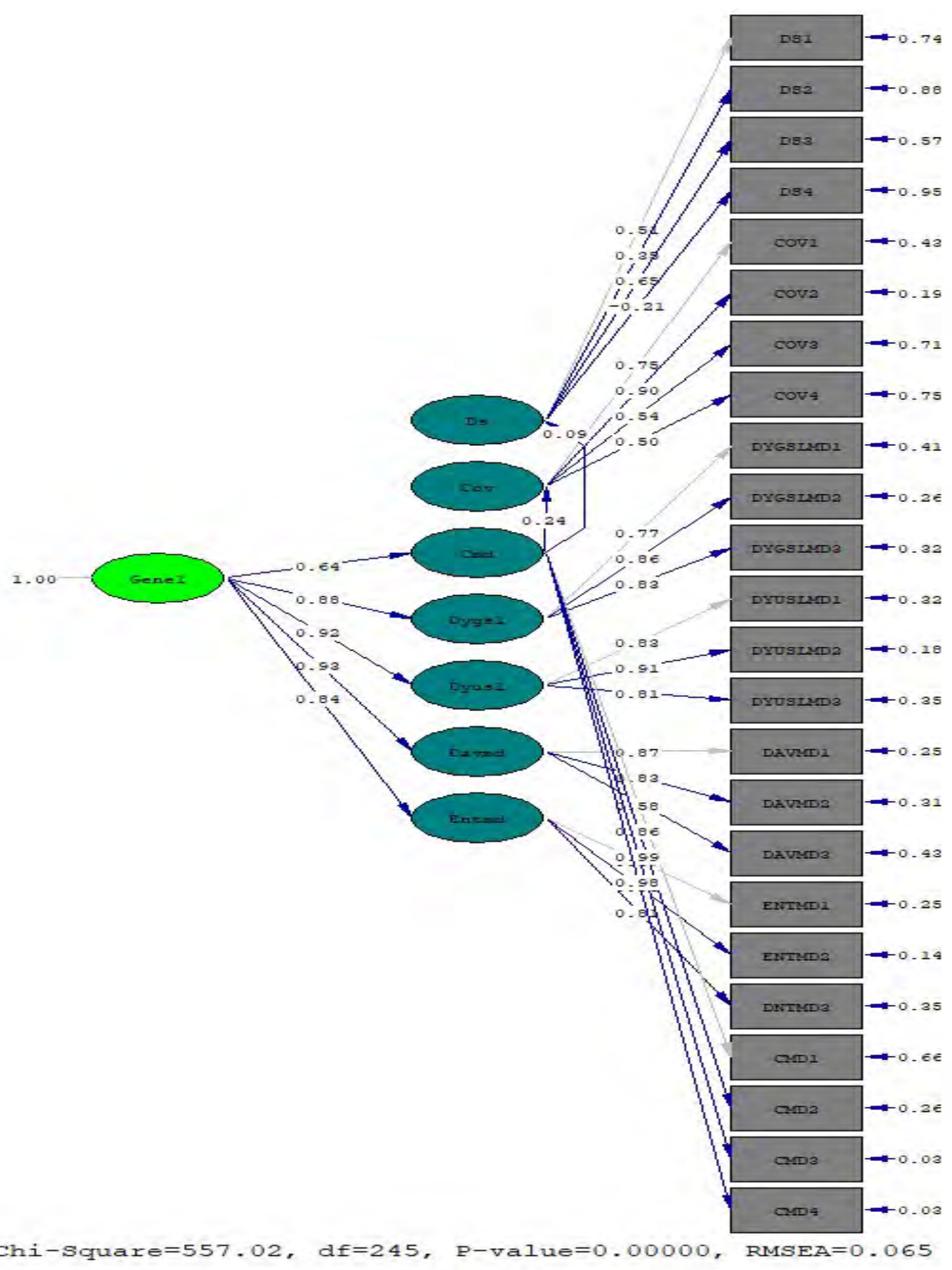

Şekil 3. Yapısal Eşitlik Modeli Standart Çözüm 
Apple ve Samsung akıllı cihaz kullanıcılarında, doğaya saygının çevre dostu marka deneyimine etkisi, anlamsız çıkmıştır ve H1 hipotezi reddedilmiş, desteklenmemiştir. Kullanıcıların sahip oldukları çevresel öz varlıkların marka deneyimine etkisi ise anlamlı çıkmıştır ve $\mathrm{H} 2$ hipotezi kabul edilmiştir. Çevre dostu marka deneyiminin genel marka deneyimine etkisi, olumlu yönde çıkmıştır ve H3 hipotezi kabul edilmiştir.

\section{Sonuç ve Tartışma}

İnsanların yaşam çizgisini, inandıkları değerler belirlemektedir. İnsanlar, sahip oldukları değerler için mücadele etmektedirler ve hatta sahip oldukları değerler uğruna ölümü bile göze almaktadırlar. Bireylerin yaşamlarında sahip oldukları değerler ile yaşadıkları çevrenin önemi dikkate alındığında; çevreyi korumanın insanlara bir değer olarak kazandırılması gerektiğinin önemi daha iyi anlaşılmaktadır (Özhancı ve Yılmaz, 2015: 40).

Günümüzde tüketiciler, sürdürülebilir tüketimi benimseyerek çevrenin korunmasına katkıda bulunma eğilimindedirler. Bununla beraber, birçok işletme, tüketicileri, "yeşil" hakkında eğitmek için çalışmalar yapmakktadır (Prakash vd., 2019: 163). Saari vd., (2017:7-8), çevre dostu olarak algılanan bir markanın, tüketicilerin ekolojik açıdan bilinçli bir yaşam tarzı izlemelerini ve tüketim alışkanlıklarında, daha sürdürülebilir olmalarını desteklediğini ifade etmiştir.

Bireyler, genel sürdürülebilir kalkınma değerleriyle ilişkili olan doğaya karşı, belirli düzeyde bir saygıya sahiptirler ve sahip oldukları öz varlıkların, çevreyi korumaya ne kadar yardımcı olabileceğine dair bir görüşe sahiptirler (Saari vd., 2020: 3). Yapılan çalışmalara göre, çevre dostu markaların farkındalığı ve bu markaları satın alma niyeti, çevreyi koruma arzusu ve çevre dostu ürünlere olan inançlar tarafından etkilenmektedir. Tüketicilerin çevre kaygıları, çevrenin korunmasına katılımlarını yansıtmaktadır (Prakash ve Pathak, 2017: 387).

Son yıllarda artan çevresel sorunlar nedeniyle, markaların çevreci yaklaşımı benimsemeleri, tüketicilerin duygu ve düşüncelerini, markaya yönelik tutumlarını, satın alma davranışlarını etkileyebilmektedir. Tüketiciler, çevre dostu ürünlere yönelik talep aracılı̆̆ıyla, çevre için artan endişelerini yönlendirmektedirler. $\mathrm{Bu}$ "yeşile yönelim" hareketi, daha sağlıklı bir şekilde yaşama konusundaki yoğun farkındalığı nedeniyle dünya çapında genişlemiştir (Suki, 2016: 2894).

Saari vd., (2017), tüketicilerin marka deneyimlerinde, çevre dostluğu yaklaşımını nasıl algıladıklarını ölçmeyi amaçlamışlardır. Bu amaçla yapılan araştırma, Hindistan ve Finlandiya'daki akıllı cihaz kullanan tüketicileri kapsamaktadır. Tüketicilerin Apple, Samsung ve Nokia markalarılla ilgili cevaplarından elde edilen verilerin analiz sonuçlarına göre, tüketicilerin genel marka deneyimlerinde, benzersiz bir çevre boyutu söz konusudur.

Araştırmada yararlanılan, Saari vd.'nin (2020) yaptıkları çalışmada, tüketicilerin doğaya saygıları, çevresel marka deneyimini olumlu yönde etkilerken; sahip oldukları öz varlıkların, çevresel marka deneyimine etkisi anlamsız çıkmıştır. Çevresel marka deneyimi ise, genel marka deneyimini olumlu yönde etkilemektedir.

Araştırmada, Apple ve Samsung akıllı cihaz kullanıcılarının, çevreye ilişkin öz varlıkları ve doğaya saygılarının, çevresel marka deneyimine etkisi, çevresel marka deneyiminin de genel marka deneyimine etkisi incelenmiştir. Çalışmada doğaya saygının, çevre dostu marka deneyimine etkisi anlamsız çımıştır. Bu doğrultuda, genel olarak doğaya saygı duyduklarını ifade eden tüketicilerin, çevreci tutumu göz ardı ederek; marka deneyimi yaşadıkları ya da markaların, çevre dostu politikaları ve eylemleri hakkında, kullanıcılarını yeteri kadar bilgilendirmedikleri ve bu yaklaşımlarını ön planda tutmakta yetersiz kaldıkları söylenebilir. Kullanıcıların çevreye ilişkin sahip olduğu öz varlıklar ise, çevre dostu marka deneyimini olumlu yönde etkilemektedir. Kullanıcıların çevre sorunları konusundaki bilgi düzeyini ve bu sorunlar karşısındaki eylemlerini, deneyimlerini, sahip oldukları değerleri içeren öz varlıkların; kullanıcıların, çevre dostu markalara karşı olan duygu ve davranışlarında yönlendirici olduğu ve marka deneyimlerinde etkili olduğu söylenebilir. Araştırmada, çevresel marka deneyiminin, genel marka deneyimine etkisi anlamlı olarak bulunmuştur. Markaların, kullanıcılarına, çevreci yaklaşımı ön plana çıkaran deneyimler sunması; kullanıcıların, genel marka deneyimini de olumlu yönde şekillendirmektedir.

Bulguların, araştırmanın örneği çerçevesinde değerlenmesi gerektiği göz önünde bulundurulmalıdır. Örnek büyüklüğü, anakütle için genelleme yapılmasına olanak tanımamaktadır. Ancak gerek yapılan araştırmada, 


\section{T. Uzunkaya 13/1 (2021) 956-968}

gerekse daha önce yapılan çalışmalar göz önünde bulundurulduğunda, markaların çevreci yaklaşımı benimsemeleri ve müşterileriyle olan iletişim ve etkileşimlerinde bunu ön plana çıkarmaları, markalar için oldukça önemlidir. Markaların, ürünlerinin sahip olduğu özelliklerin tanıtımı konusundaki faaliyetlerinin yanı sıra sürdürülebilirlik konusundaki çalışma ve politikalarını, sürdürülebilir kalkınmaya olan katkılarını, müşterilerine aktararak; bu konudaki farkındalığı artırabilirler ve müşterilerin marka deneyiminde olumlu bir etki yaratabilirler.

Araştırmada baz alınan, kendini teknoloji ve yenilikler konusunda kanıtlayan, Apple ve Samsung da dahil olmak üzere, markaların çevreci yaklaşım konusundaki tutumlarını daha yoğun bir şekilde göstermeleri ve müşterilerini de bu konuda teşvik etmeleri, markaların, hem farkındalık yaratmasına hem de rekabetçi konumlarını güçlendirmelerine katkı sağlayacaktır. Bunun yanı sıra genel olarak yapılan çalışmalardaki bulgulara bakıldığında, çevre dostu markaların sunduğu deneyimlerin, genel marka deneyimlerini olumlu yönde etkilediğini söylemek mümkündür.

Araştırmada ele alınan, tüketicilerin akıllı telefon marka deneyimlerinde ön plana çıkan çevreci yaklaşımın, tüketicilerin kullandıkları diğer ürünlerde ya da farklı sektörlerde uygulanarak, elde edilen sonuçları destekleyip desteklemediğinin incelenmesi yararlı olacaktır. Çevre dostluğunu ölçmek için marka deneyimi ölçümü ile ilgili geliştirilen ölçeğin, daha geniş bir örneklem hacmine uygulanması, elde edilen sonuçların geçerliliğine olan katkıyı arttıracaktır.

\section{KAYNAKÇA}

Arya, V., Sethi, D. and Paul, J. (2019). Does digital footprint act as a digital asset? -Enhancing brand experience through remarketing, International Journal of Information Management, 49, 142-156.

Blasi, S., Brigato, L. and Sedita, S.R. (2020). Eco-friendliness and fashion perceptual attributes of fashion brands: An analysis of consumers' perceptions based on twitter data mining, Journal of Cleaner Production, 244, 1-11.

Brakus, J.J., Schmitt, B.H. and Zarantonello L. (2009). Brand experience: What is it? How is it measured? Does it affect loyalty?, Journal of Marketing, 73(3), 52-68.

Campbell, B., Khachatryan, H., Behe, B., Dennis, J. and Hall, C. (2015). Consumer perceptions of eco-friendly and sustainable terms, Agricultural and Resource Economics Review, 44(1), 21-34.

Groening, C., Sarkis, J. and Zhu, Q. (2018). Green marketing consumer-level theory review: A compendium of applied theories and further research directions, Journal of Cleaner Production, 172, 1848-1866.

Han, H., Hsu, L.T.J., Lee, J.S. and Sheu, C. (2011). Are lodging customers ready to go green? An examination of attitudes, demographics, and eco-friendly intentions, International journal of Hospitality Management, 30, 345-355.

Jeong, G.Y., Im, C.C. and Kim, M.S. (2017). The effect of brand experience provider on brand experience: focus on Korean cosmetic brand shop, The Journal of Applied Business Research, 33(6), 1205-1228.

Keng, C.J., Tran, V.D. and Thi, T.M.L. (2013). Relationships among brand experience, brand personality, and customer experiential value, Contemporary Management Research, 9(3), 247-262.

Kim, D.H. and Song, D. (2019). Can brand experience shorten consumers' psychological distance toward the brand? The effect of brand experience on consumers' construal level, Journal of Brand Marketing, 26, 255267.

Kumagai, K. and Nagasawa, S. (2020). Launch of sustainable plastic apparel: Effects of brand luxury and experience on consumer behaviour, Sustainability, 12(18), 1-15.

Oh, J., Connerton, T.P. and Kim, H.J. (2020). The Rediscovery of Brand Experience Dimensions with Big Data Analysis: Building for a Sustainable Brand, Sustainability, 11(19), 1-21.

Özhancı, E. and Yılmaz, H. (2015). Doğa sevgisi değeri (doğayı koruma ve doğadan yararlanma) ve peyzaj mimarlığ1 eğitimi, Journal of Tekirdag Agricultural Faculty, 12(1), 39-45. 


\section{T. Uzunkaya 13/1 (2021) 956-968}

Paparoidamis, N.G. and Tran, H.T.T. (2019). Making the world a better place by making better products- ecofriendly consumer innovativeness and the adoption of eco-innovations, European Journal of Marketing, 53(8), 1546-1584.

Pina, R. and Dias, A. (2021). The infuence of brand experiences on consumer-based brand equity, Journal of Brand Management, 28, 99-115.

Prakash, G., Choudhary, S., Kumar, A., Garza-Reyes, J.A., Khan, S.A.R. and Panda, T.K. (2019). Do altruistic and egoistic values influence consumers' attitudes and purchase intentions towards eco-friendly packaged products? An empirical investigation, Journal of Retailing and Consumer Services, 50, 163-169.

Prakash, G. and Pathak, P. (2017). Intention to buy eco-friendly packaged products among young consumers of India: A study on developing nation. Journal of Cleaner Production, 141, 385-393.

Prentice, C., Wang, X. and Loureiro, S.M.C. (2019). The influence of brand experience and service quality on customer engagement, Journal of Retailing and Consumer Services, 50, 50-59.

Ramaseshan, B. and Stein, A. (2014). Connecting the dots between brand experience and brand loyalty: The mediating role of brand personality and brand relationships, Journal of Brand Management, 21, 664-683.

Saari, U.A., Baumgartner, R.J. and Mäkinen, S.J. (2017). Eco-friendly brands to drive sustainable development: replication and extension of the brand experience scale in a cross-national context, Journal of Sustainability, 9(7), 1-26.

Saari, U.A., Mäkinen, S.J., Baumgartner, R.J., Hillebrand B. and Driessen, P.H. (2020). How consumers' respect for nature and environmental self-assets influence their car brand experiences, Journal of Cleaner Production, 261, 1-11.

Schultz, P.W. and Zelezny, L. (1999). Values as predictors of environmental attitudes: Evidence for consistency across 14 countries, Journal of Environmental Psychology, 19(3), 255-265.

Shepherd, D.A., Kuskova, V. and Patzelt, H. (2009). Measuring the values that underlie sustainable development: The development of a valid scale, Journal of Economic Psychology, 30(2), 246-256.

Shepherd, D.A., Patzelt, H. and Baron, R.A. (2013). "I care about nature, but...": Disengaging values in assessing opportunities that cause harm, The Academy of Management Journal, 56(5), 1251-1273.

Simão, L. and Lisboa, A. (2017). Green marketing and green brand - The Toyota case, Procedia Manufacturing, $12,183-194$.

Sonenshein, S., DeCelles, K.A. and Dutton, J.E. (2014). It's not easy being green: The role of self-evaluations in explaining support of environmental issues, The Academy of Management Journal, 57(1). 7-37.

Suki, N.M. (2016). Green product purchase intention: Impact of green brands, attitude, and knowledge, British Food Journal, 118(12), 2893-2910.

Şimşek, Ö.F. (2007). Yapısal Eşitlik Modellemesine Giriş - Temel İlkeler ve LISREL Uygulamaları. Ankara, Siyasal Kitap Basın Yayın Dağıtım.

Trivedi, R.H., Patel, J.D. and Acharya, N. (2018). Causality analysis of media influence on environmental attitude, intention and behaviors leading to green purchasing, Journal of Cleaner Production, 196, 11-22.

Yükselen, C. (2017). Pazarlama Araştırmaları. Ankara, Detay Yayıncılık.

https://www.apple.com/tr/ (Erişim Tarihi: 8 Haziran 2020).

https://www.samsung.com/tr/ (Erişim Tarihi: 8 Haziran 2020). 